\title{
Frondicola australicus gen. nov., sp. nov., isolated from decaying leaf litter from a pine forest
}

\author{
Correspondence \\ Bharat Patel \\ b.patel@griffith.edu.au
}

\author{
Li Zhang, ${ }^{1}$ Zhihong $\mathrm{Xu}^{2}$ and Bharat K. C. Patel ${ }^{1}$ \\ ${ }^{1}$ Microbial Gene Research and Resources Facility, School of Biomolecular and Biomedical \\ Sciences, Faculty of Science, Griffith University, Brisbane, OLD 4111, Australia \\ ${ }^{2}$ Center for Forestry and Horticultural Research, Faculty of Science, Griffith University, \\ Brisbane, OLD 4111, Australia
}

Nutrients released from the microbial decomposition of plant residues, such as leaf litter, in both natural and agricultural ecosystems, are important for plant growth. It is well known that the quantity of leaf litter decreases during the process of decomposition due to the loss of readily available carbon with a concomitant increase in microbial numbers and an accumulation of refractory compounds (Wardle et al., 2006). Extensive studies on the culturedependent and culture-independent microbial diversity of soils and the plant rhizosphere and, to a lesser extent, the leaf litter biosphere, have suggested that members of the phyla Actinobacteria and Proteobacteria dominate these environments (Sharma et al., 2005; Xu et al., 1996). During our culture-dependent and culture-independent bacterial diversity studies of the leaf litter of a slash pine forest located in southeast Queensland, Australia, we frequently isolated members of the phylum Actinobacteria. Here, we report on

Abbreviation: DSMZ, Deutsche Sammlung von Mikroorganismen und Zellkulturen.

The GenBank/EMBL/DDBJ accession number for the 16S rRNA gene sequence of Frondicola australicus sp. nov. strain $\mathrm{E} 1 \mathrm{HC}-02^{\top}$ is D052589.

Details of the cellular fatty acid content of strain $\mathrm{E} 1 \mathrm{HC}-02^{\top}$ are available as a supplementary table with the online version of this paper. the characteristics of an irregular rod-shaped bacterium, designated strain E1HC- $02^{\mathrm{T}}$, which represents a novel species of a new genus.

For the isolation of strain E1HC- $02^{\mathrm{T}}, 10 \mathrm{~g}$ of moist leaf litter was mixed with $50 \mathrm{ml}$ of sterile distilled water and vortexed for $5 \mathrm{~min}$. The suspension was then rocked horizontally for $5 \mathrm{~min}$, serially diluted ten-fold and $100 \mu \mathrm{l}$ of the mixture was spread onto trypticase soy broth (TSB) Gelrite plates, $\mathrm{pH}$ 7.2. The Gelrite plates contained $\left(\mathrm{g} \mathrm{l}^{-1}\right) 3 \mathrm{~g}$ TSB, $2.033 \mathrm{~g} \mathrm{MgCl}_{2} \cdot 6 \mathrm{H}_{2} \mathrm{O}, 0.882 \mathrm{~g} \mathrm{CaCl}_{2} \cdot 2 \mathrm{H}_{2} \mathrm{O}$ and $20 \mathrm{~g}$ Gelrite. The plates were incubated at room temperature (approx. $25^{\circ} \mathrm{C}$ ) for up to 6 days. Several morphologically distinct single colonies that developed were picked and individually restreaked onto fresh TSB Gelrite plates at least twice before being considered pure. Colonies from pure cultures were resuspended in sterile preservation medium (0.3 g TSB, $15 \mathrm{ml}$ glycerol and $85 \mathrm{ml}$ distilled water) and stored at $-80^{\circ} \mathrm{C}$. One of the isolates that produced cream, round, smooth colonies within 3 days of incubation was designated strain E1HC- $02^{\mathrm{T}}$ and selected for further characterization.

Cell morphology was determined by phase-contrast and electron microscopy (Kanso \& Patel, 2003). Cells of strain E1HC-02 ${ }^{\mathrm{T}}$ were non-flagellated and non-sporulating irregular short rods $(0.5-1.0 \times 0.2-0.4 \mu \mathrm{m})$. Electron 


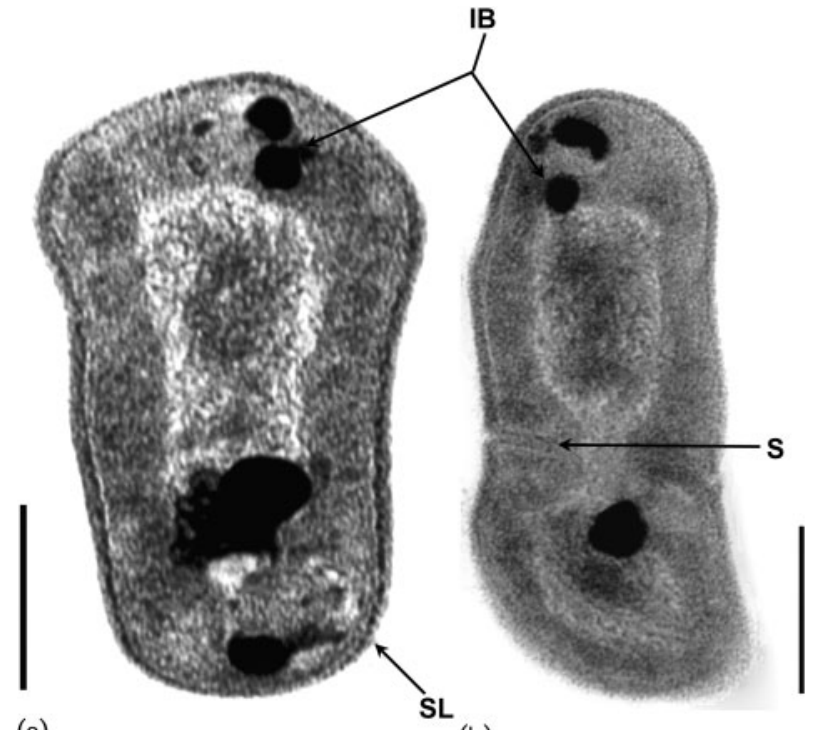

(a)

(b)

Fig. 1. $(a, b)$ Transmission electron micrographs of thin sections of cells of Frondicola australicus sp. nov. E1 $\mathrm{HC}-02^{\top}$ showing irregular rod-shaped cells with inclusion bodies (IB), a typical Gram-positive cell-wall ultrastructure with an $S$ layer $(\mathrm{SL})$, and septum (S) formation during cell division. Bars, $200 \mathrm{~nm}$.

micrographs of thin sections revealed a Gram-positive cellwall ultrastructure with an S-layer (Messner \& Sleytr, 1992; Sleytr et al., 1988) and electron-dense inclusion bodies (Fig. 1).

Growth of strain E1HC- $02^{\mathrm{T}}$ was tested in different concentrations of TSB (up to $3 \%$ ) with temperatures ranging from 4 to $50{ }^{\circ} \mathrm{C}$ and $\mathrm{pH}$ values ranging from 5.1 to 9.5 . Growth was measured at $660 \mathrm{~nm}$ in a Novaspec LKB spectrophotometer (Pharmacia-Biotech Pty. Ltd.). Strain E1HC- $02^{\mathrm{T}}$ grew optimally in $1 \% \mathrm{TSB}$ at a $\mathrm{pH}$ of $9.1(\mathrm{pH}$ growth range, 6.0-9.5) and an incubation temperature of $25^{\circ} \mathrm{C}$ (growth temperature range $15-37^{\circ} \mathrm{C}$ ) with a generation time of $5 \mathrm{~h}$. Unless indicated otherwise, all subsequent growth experiments were conducted using these conditions.

The metabolic profile of strain E1HC- $02^{\mathrm{T}}$ was determined using GN2 Biolog plates (Hayward). For this, the novel strain was grown on Biolog Universal Growth medium agar plates. Colonies were resuspended in an inoculation fluid and this was used to inoculate the wells of GN2 Biolog plates as recommended by the manufacturer. After $24 \mathrm{~h}$ incubation at room temperature (approx. $25^{\circ} \mathrm{C}$ ), the absorbances in the wells of the microtitre plates were read and the results transformed into positive, borderline and negative scores by using Biolog MicroStation System software. The results of the analysis are provided in the species description.

Catalase activity was determined by dropping $\mathrm{H}_{2} \mathrm{O}_{2}$ on to colonies that developed on $1 \%$ TSB agar plates and activity was determined to be positive. The oxidase test, determined by using Oxidase detection strips (Medvet Science Pty. Ltd.), was negative.

The cell-wall peptidoglycan of strain E1HC- $02^{\mathrm{T}}$ was isolated and analysed at the Deutsche Sammlung von Mikroorganismen und Zellkulturen (DSMZ), Germany, using previously described procedures (MacKenzie, 1987; Schleifer, 1985; Schleifer \& Kandler, 1972; Rhuland et al., 1955). The total hydrolysate was found to contain the amino acids ornithine, alanine, glycine, homoserine and glutamic acid in the molar ratio of $1.0: 0.9: 1.7: 0.5: 1.0$. The presence of these amino acids was confirmed by GC and MS (MacKenzie, 1984). Hydroxyglutamic acid was not detected. The partial hydrolysate of the cell-wall peptidoglycan showed that strain E1HC- $02^{\mathrm{T}}$ contained the peptides GlyL-Glu and D-Orn-D-Ala. On the basis of amino acid and peptide analyses of cell-wall hydrolysates, strain E1HC- $02^{\mathrm{T}}$ was determined to contain a peptidoglycan of type B2 $\beta$ $\{$ Gly\} [L-Hsr] D-Glu-D-Orn (Schleifer \& Kandler, 1972). No glycolate was detected in the cell-wall acid hydrolysate, which suggests that muramic acid occurs in the $\mathrm{N}$-acetyl form.

Fatty acid methyl ester (FAME) analysis of the whole-cell was determined at DSMZ using GC (MIDI, Microbial ID). Strain E1HC-02 ${ }^{\mathrm{T}}$ possessed a very large amount of fatty acid $18: 1 \omega 7 c(77.9 \%)$ and smaller amounts of other fatty acids (see Supplementary Table S1 in IJSEM Online).

Polar lipid analysis was carried out by the identification services of DSMZ and Dr B. J. Tindall, DSMZ, Germany. Strain E1HC- $02^{\mathrm{T}}$ possessed disphosphatidylglycerol, phosphatidylglycerol, at least 6 glycolipids, of which 3 were probably diglycosyl diglycerides (the nature of sugars and their linkages have not been identified), and 4 unidentified phospholipids.

For genomic DNA purification, a $50 \mathrm{ml}$ sample of actively growing culture was centrifuged at 5400 r.p.m. at $4{ }^{\circ} \mathrm{C}$ for $20 \mathrm{~min}$ (4K15; Sigma) and the cell pellet was resuspended in $4 \mathrm{ml}$ buffer A (5 mM Tris/ $\mathrm{HCl} \mathrm{pH} 8.0,100 \mathrm{mM} \mathrm{NaCl}$ and $5 \mathrm{mg}$ lysozyme). After incubation on ice for $5 \mathrm{~min}, 0.85 \mathrm{ml}$ of buffer [300 mM EDTA, pH 7.5 and $5 \%$ (w/v) SDS] and $100 \mu \mathrm{l}$ of $20 \mathrm{mg} \mathrm{ml}^{-1}$ proteinase $\mathrm{K}$ was added. Following overnight incubation at $55^{\circ} \mathrm{C}$, an equal volume of phenol: chloroform : isoamylalcohol $(25: 24: 1)$ was added and the mixture was agitated gently for $30 \mathrm{~min}$. Three volumes of cold $100 \%$ ethanol were then carefully overlaid and the flocculent DNA that developed was spooled onto a sterile disposable plastic loop. The spooled DNA was re-

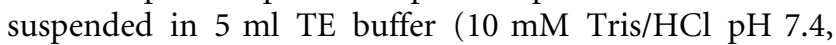
$1 \mathrm{mM}$ EDTA pH 8 ) and the quality assessed by agarose gel electrophoresis, ethidium bromide staining and visualization under a Gel Documentation Analysis System (GDAS 1200; UVP). The mol\% G + C content of the genomic DNA was determined by the thermal denaturation method (Marmur \& Doty, 1961) using a spectrophotometer (Cintra20; GBC Scientific Equipment) as described by Spanevello et al., 2002 and was calculated to be $71 \pm 1 \mathrm{~mol} \%$. 
For studies on the $16 \mathrm{~S}$ rRNA gene, $10 \mathrm{ml}$ of an overnight culture of strain E1HC- $02^{\mathrm{T}}$ was centrifuged at 5400 r.p.m. at $4{ }^{\circ} \mathrm{C}$ for $20 \mathrm{~min}$ (4K15; Sigma). The pellet was resuspended in $100 \mu \mathrm{l} \mathrm{TE}$ buffer and the cells were lysed by boiling for $15 \mathrm{~min}$. The lysate was centrifuged at 14000 r.p.m. for $15 \mathrm{~min}$ in a microcentrifuge (model 1-15; Sigma) and $2 \mu \mathrm{l}$ aliquots of the supernatant were used as a template for the amplification of the 16S rRNA gene (Andrews \& Patel, 1996). The sequencing of the gene was performed essentially as described previously (Andrews \& Patel, 1996). The partial sequences that were generated were assembled using BioEdit v5.0.1 (Hall, 1999) and the consensus sequence of 1433 nucleotides was manually corrected for errors. The most closely related sequences in GenBank (version 152) and the Ribosomal Database Project II (release 9.37) identified using BLAST (Altschul et al., 1997) and the Sequence Match program (Cole et al., 2005) were extracted, aligned and manually adjusted according to the 16S rRNA secondary structure using BioEdit. Nucleotide ambiguities were omitted and evolutionary distances were calculated by using the Jukes and Cantor option (Jukes \& Cantor, 1969) in TreeCon (Van de Peer et al., 1997). Phylogenetic trees were constructed from evolutionary distances using the neighbour-joining method (Saitou \& Nei, 1987). Tree topology was re-examined by the bootstrap method (1000 replications) of resampling (Felsenstein, 1985).

$16 \mathrm{~S}$ rRNA gene sequence analysis indicates that strain E1HC- $02^{\mathrm{T}}$ is a member of the phylum Actinobacteria, class Actinobacteria, subclass Actinobacteridae, order
Actinomycetales, suborder Micrococcineae, family Microbacteriaceae (Fig. 2). The inclusion of strain $\mathrm{E} 1 \mathrm{HC}-02^{\mathrm{T}}$ as a member of the phylum to the suborder level is supported by the presence of the defining nucleotide signatures and, with the exception of an A:U at the positions 771-808 (Escherichia coli numbering) instead of a G:C, to the family level (Stackebrandt et al., 1997). Phylogenetic analysis undertaken with representative members of the family Microbacteriaceae placed strain E1HC- $02^{\mathrm{T}}$ almost equidistantly between the cluster represented by the strains of the psychrophile Frigoribacterium faeni (Miteva et al., 2004; Kämpfer et al., 2000) and an isolate from alpine subnival plants (H. M. Sheng, L. Z. Ang, S. J. Xu, T. Chen \& X. L. Zheng, unpublished, GenBank accession no. DQ339615) and a $16 \mathrm{~S}$ rRNA clone from DNA extracted from volcanic deposits (J. Gomez-Alvarez, J. Baniak, G. Harrison, J. G. Medrano \& K. Nusslein, unpublished, GenBank accession no. DQ490454). This relationship was not robust when the sequences of the 16S rRNA clone and the alpine subnival plant isolate sequences were excluded from the analysis, suggesting that strain $\mathrm{E} 1 \mathrm{HC}-02^{\mathrm{T}}$ is only distantly related to Frigoribacterium faeni. The phylogenetic analysis, taken together with the information that strain $\mathrm{E} 1 \mathrm{HC}-02^{\mathrm{T}}$ possesses a protein subunit cell-wall ultrastructure, is unable to grow at psychrophilic temperatures, has a higher optimum $\mathrm{pH}$ for growth and has a number of significant chemotaxonomic differences in its cell wall and cell membranes and in its metabolizable substrates (Table 1), clearly differentiates the novel strain from members of the genus Frigoribacterium.

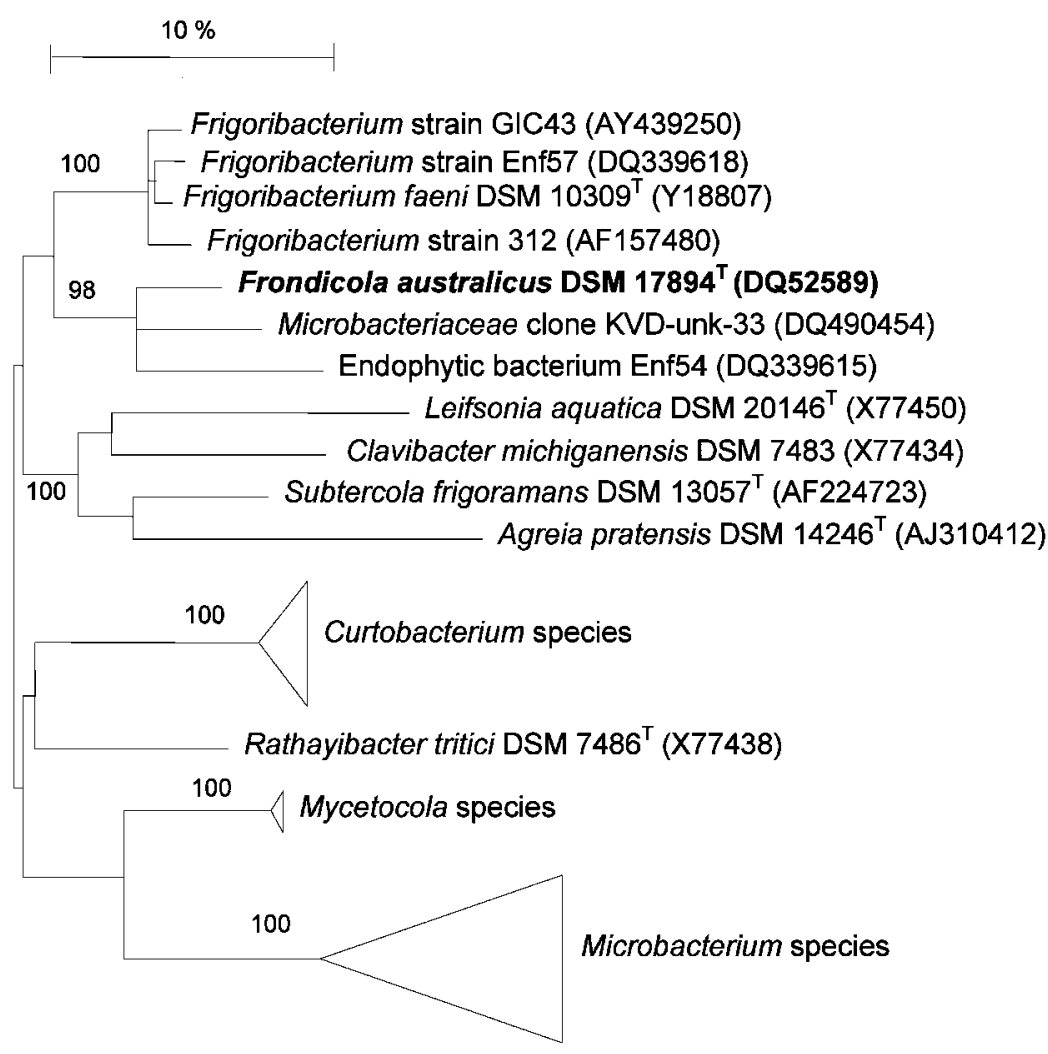

Fig. 2. Neighbour-joining phylogenetic tree showing the position of Frondicola australicus sp. nov. $\mathrm{E} 1 \mathrm{HC}-02^{\top}$ within the radiation of members of the family Microbacteriaceae. GenBank accession numbers are given in parentheses. Clusters of members of the same genus are represented as triangles and include Mycetocola saprophilus DSM $15178^{\top}$ (GenBank accession no. AB012647) and Mycetocola tolaasinivorans DSM $15179^{\top}$ (AB012646) for the genus Mycetocola, Microbacterium imperiale DSM $20530^{\top}$ (X77442), Microbacterium phyllosphaerae DSM 13468 ${ }^{\top}$ (AJ277840), Microbacterium liquefaciens DSM 20638 ${ }^{\top}$ (X77444) and Microbacterium thalassium DSM $12511^{\top}$ (AM181507) for the genus Microbacterium and Curtobacterium citreum DSM 20528 ${ }^{\top}$ (X77436) and Curtobacterium flaccumfaciens LMG $3645^{\top}$ (AJ312209) for the genus Curtobacterium. Bootstrap values above $95 \%$ from 1000 replicates are shown. Bar, $10 \%$ change per nucleotide. 
Table 1. Key characteristics that differentiate genera of the family Microbacteriaceae

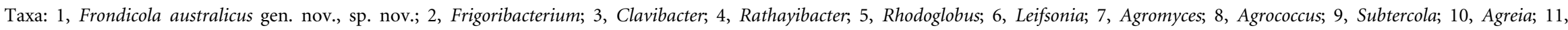

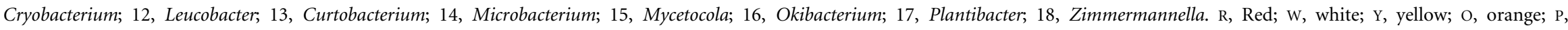

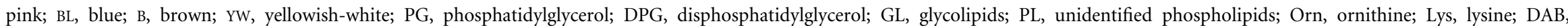
diaminobutyric acid; NR, not reported.

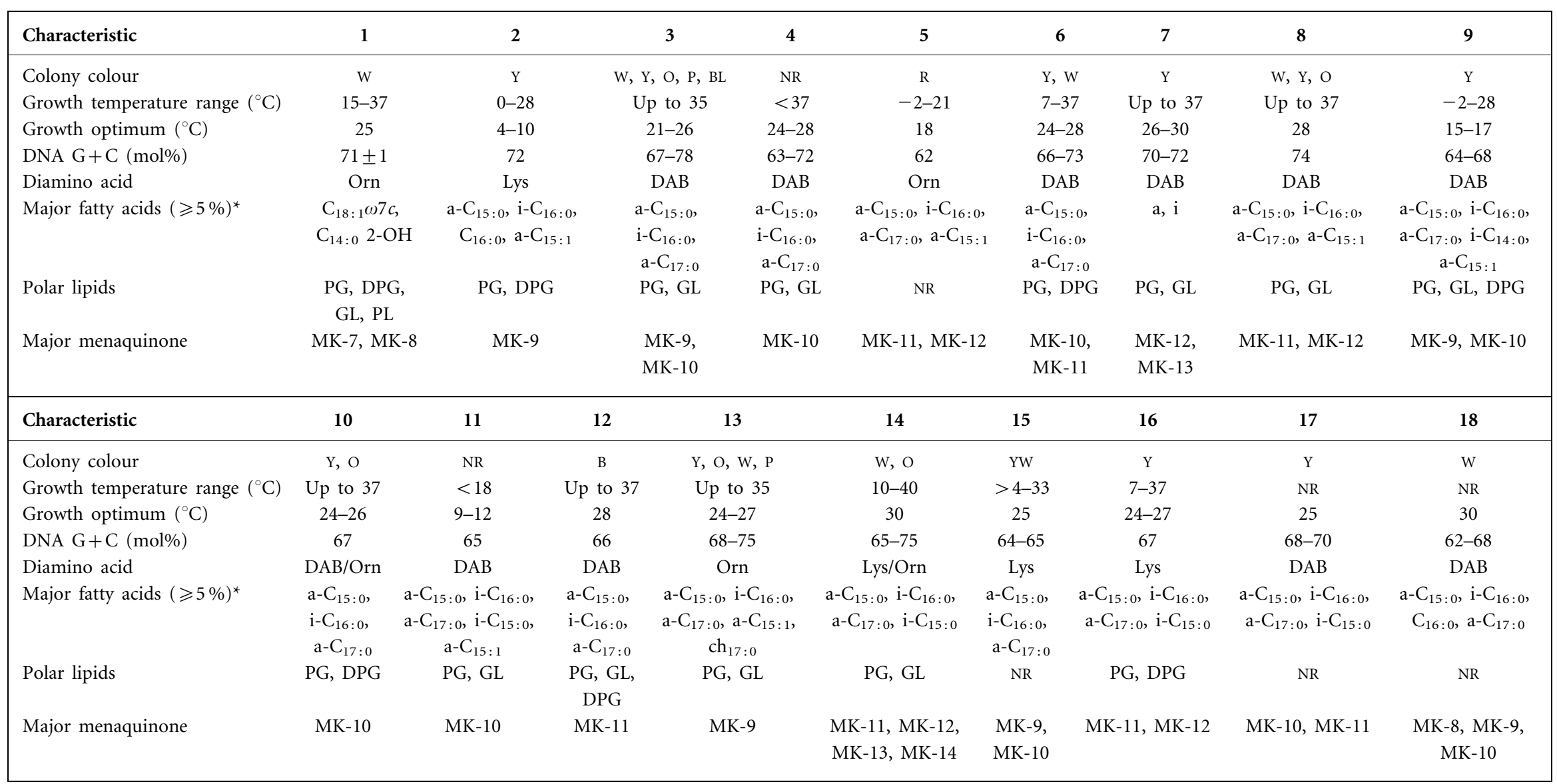

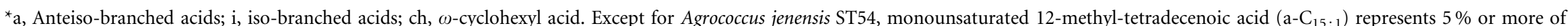
the total only when the strains were grown at lower temperatures $\left(10^{\circ} \mathrm{C}\right)$. 
The members of the family Microbacteriaceae form a cohesive phylogenetic cluster and the 17 genera of the family are further defined and differentiated by key chemotaxonomic characteristics, as indicated in Table 1. Strain E1HC- $02^{\mathrm{T}}$, however, possesses traits that are atypical and have so far not been reported for any of the genera of the family Microbacteriaceae, including the genus Frigoribacterium (Table 1). Strain E1HC- $02^{\mathrm{T}}$ contains a high concentration of the monounsaturated fatty acid $18: 1 \omega 7 c(78 \%)$, a fatty acid reported so far only in a few members of the class Alphaproteobacteria (Kim et al., 2006; Martínez-Cánovas et al., 2004), possesses a type B2 $\beta$ cell-wall peptidoglycan, has MK-8 and MK-7 as the major menaquinones and contains the glycolipids disphosphatidylglycerol, phosphatidylglycerol and three unidentified phospholipids.

Based on the phylogenetic, chemotaxonomic and phenotypic evidence presented, strain E1HC- $02^{\mathrm{T}}$ cannot be placed in any of the 17 genera of the family Microbacteriaceae and hence we propose to create a new genus, Frondicola gen. nov., to accommodate this novel species. Strain E1HC- $02^{\mathrm{T}}$ represents the type strain of the type species, Frondicola australicus sp. nov.

\section{Description of Frondicola gen. nov.}

Frondicola [Fron.di' co.la. L. fem. n. frons (genitive, frondis) fallen leaves; L. masc. suffix n. -cola from incola inhabitant; N.L. masc. n. Frondicola inhabitant of leaves, leaf dweller].

Cells are aerobic, non-endospore-forming, irregular-shaped rods which stain Gram-positive. No mycelium is produced. A range of carbohydrates, organic compounds and amino acids are metabolized. 16S rRNA gene sequence analysis indicates that the genus is a member of the family Microbacteriaceae within the radiation of the genus Frigoribacterium. The cell-wall peptidoglycan type is $\mathrm{B} 2 \beta$, the major cellular fatty acid is $18: 1 \omega 7 c$ and menaquinones MK-7 and MK-8 are present. The type species is Frondicola australicus.

\section{Description of Frondicola australicus sp. nov.}

Frondicola australicus (aus.tra'li.cus. N.L. masc. adj. australicus pertaining to Australia, from where the type strain was isolated).

Has the following properties in addition to those given in the description of the genus. Cells are non-motile, non-sporeforming, aerobic, irregular, short rods $(0.5-1.0 \times 0.2-$ $0.4 \mu \mathrm{m})$ that stain Gram-positive. Cell wall appears to be made of a protein subunit layer and inclusion bodies are present. Growth occurs at temperature between 15 and $37^{\circ} \mathrm{C}$ (optimum temperature, $25^{\circ} \mathrm{C}$ ) and at $\mathrm{pH}$ 6.0-9.5 (optimum, $\mathrm{pH}$ 9.1). The type strain metabolizes dextrin, Tween 40, Tween 80, maltose, D-melibiose, $\alpha$-D-glucose, sucrose, D-trehalose, turanose, succinic acid monomethyl ester, $\alpha$-ketobutyric acid, $\alpha$-ketoglutaric acid, $\alpha$-ketovaleric acid, DL-lactic acid, L-glutamic acid, L-pyroglutamic acid and urocanic acid. Does not metabolize $\alpha$-cyclodextrin, glycogen, $\quad N$-acetyl-D-galactosamine, $\quad N$-acetyl-D-glucosamine, adonitol, L-arabinose, D-arabitol, D-cellobiose, ierythritol, D-fructose, L-fucose, D-galactose, gentiobiose, myo-inositol, $\alpha$-D-lactose, lactulose, D-mannitol, D-mannose, methyl $\beta$-D-glucoside, D-psicose, D-raffinose, L-rhamnose, D-sorbitol, xylitol, pyruvic acid methyl ester, acetic acid, cis-aconitic acid, citric acid, formic acid, D-galactonic acid lactone, D-galacturonic acid, D-gluconic acid, D-glucosaminic acid, D-glucuronic acid, $\alpha$-hydroxybutyric acid, $\beta$-hydroxybutyric acid, $\gamma$-hydroxybutyric acid, p-hydroxyphenylacetic acid, itaconic acid, malonic acid, propionic acid, quinic acid, D-saccharic acid, sebacic acid, succinamic acid, glucuronamide, L-alaninamide, L-alanine, D-alanine, L-alanyl glycine, L-asparagine, L-aspartic acid, glycyl L-glutamic acid, L-histidine, hydroxy-L-proline, L-leucine, L-ornithine, L-phenylalanine, L-proline, L-serine, D-serine, L-threonine, DL-carnitine, $\gamma$-aminobutyric acid, inosine, uridine, thymidine, phenylethylamine, 2-aminoethanol, 2,3-butanediol, glycerol, DL- $\alpha$-glycerol phosphate, $\alpha$-Dglucose 1-phosphate or D-glucose 6-phosphate. Catalasepositive and oxidase-negative. The type B2 $\beta\{$ Gly $\}$ [L-Hsr] D-Glu-D-Orn peptidoglycan contains the amino acids ornithine, alanine, glycine, homoserine and glutamic acid in a molar ratio of $1.0: 0.9: 1.7: 0.5: 1.0$, respectively. The major cellular fatty acid is $18: 1 \omega 7 c(78 \%)$ and the major menaquinones detected are MK-8 (76\%) and MK-7 (24\%). The glycolipids disphosphatidylglycerol, phosphatidylglycerol and three unidentified phospholipids are present. The DNA base content is $71 \pm 1 \mathrm{~mol} \% \mathrm{G}+\mathrm{C}$.

The type strain, strain E1HC- $02^{\mathrm{T}}\left(=\mathrm{JCM} 13598^{\mathrm{T}}=\mathrm{DSM}\right.$ $17894^{\mathrm{T}}$ ), was isolated from the decaying leaf litter of a slash pine forest located in southeast Queensland, Australia.

\section{References}

Altschul, S. F., Madden, T. L., Schäffer, A. A., Zhang, J., Zhang, Z., Miller, W. \& Lipman, D. J. (1997). Gapped BLAST and PSI-BLAST: a new generation of protein database search programs. Nucleic Acids Res 25, 3389-3402.

Andrews, K. T. \& Patel, B. K. C. (1996). Fervidobacterium gondwanense sp. nov., a new thermophilic anaerobic bacterium isolated from nonvolcanically heated geothermal waters of the Great Artesian Basin of Australia. Int J Syst Bacteriol 46, 265-269.

Cole, J. R., Chai, B., Farris, R. J., Wang, Q., Kulam, S. A., McGarrell, D. M., Garrity, G. M. \& Tiedje, J. M. (2005). The Ribosomal Database Project (RDP-II): sequences and tools for high-throughput rRNA analysis. Nucleic Acids Res 33 (Database issue), D294-D296.

Felsenstein, J. (1985). Confidence limits on phylogenies: an approach using the bootstrap. Evolution 39, 783-791.

Hall, T. A. (1999). BioEdit: a user-friendly biological sequence alignment editor and analysis program for Windows 95/98/NT. Nucleic Acids Symp Ser 41, 95-98.

Jukes, T. H. \& Cantor, C. R. (1969). Evolution of protein molecules. In Mammalian Protein Metabolism, pp. 21-123. Edited by H. N. Munro. New York: Academic Press.

Kämpfer, P., Rainey, F. A., Andersson, M. A., Nurmiaho Lassila, E. L., Ulrych, U., Busse, H. J., Weiss, N., Mikkola, R. \& Salkinoja-Salonen, M. (2000). Frigoribacterium faeni gen. nov., sp. nov., a novel 
psychrophilic genus of the family Microbacteriaceae. Int J Syst Evol Microbiol 50, 355-363.

Kanso, S. \& Patel, B. K. C. (2003). Microvirga subterranea gen. nov., sp. nov., a moderate thermophile from a deep subsurface Australian thermal aquifer. Int J Syst Evol Microbiol 53, 401-406.

Kim, B. C., Park, J. R., Bae, J. W., Rhee, S. K., Kim, K. H., Oh, J. W. \& Park, Y. H. (2006). Stappia marina sp. nov., a marine bacterium isolated from the Yellow Sea. Int J Syst Evol Microbiol 56, 75-79.

MacKenzie, S. L. (1984). Amino acids and peptides. In Gas Chromatography/Mass Spectrometry Applications in Microbiology, pp. 157-204. Edited by G. Odham, L. Larsson \& P. Mardh. New York: Plenum.

MacKenzie, S. L. (1987). Gas chromatographic analysis of amino acids as the N-heptafluorobutyryl isobutyl esters. J Assoc Off Anal Chem 70, 151-160.

Marmur, J. \& Doty, P. (1961). Thermal renaturation of deoxyribonucleic acids. J Mol Biol 3, 585-594.

Martínez-Cánovas, M. J., Quesada, E., Martínez-Checa, F., del Moral, A. \& Béjar, V. (2004). Salipiger mucescens gen. nov., sp. nov., a moderately halophilic, exopolysaccharide-producing bacterium isolated from hypersaline soil, belonging to the $\alpha$-Proteobacteria. Int $J$ Syst Evol Microbiol 54, 1735-1740.

Messner, P. \& Sleytr, U. B. (1992). Crystalline bacterial cell-surface layers. Adv Microb Physiol 33, 213-275.

Miteva, V. I., Sheridan, P. P. \& Brenchley, J. E. (2004). Phylogenetic and physiological diversity of microorganisms isolated from a deep Greenland glacier ice core. Appl Environ Microbiol 70, 202-213.

Rhuland, L. E., Work, E., Denman, F. R. \& Hoare, D. S. (1955). The behavior of the isomers of $\alpha, \varepsilon$-diaminopimelic acid on paper chromatograms. J Am Chem Soc 77, 4844-4846.
Saitou, N. \& Nei, M. (1987). The neighbor-joining method: a new method for reconstructing phylogenetic trees. Mol Biol Evol 4, 406-425.

Schleifer, K. H. (1985). Analysis of the chemical composition and primary structure of murein. Methods Microbiol 18, 123-156.

Schleifer, K. H. \& Kandler, O. (1972). Peptidoglycan types of bacterial cell walls and their taxonomic implications. Bacteriol Rev 36, 407-477.

Sharma, S., Aneja, M. K., Mayer, J., Munch, J. C. \& Schloter, M. (2005). Characterization of bacterial community structure in rhizosphere soil of grain legumes. Microb Ecol 49, 407-415.

Sleytr, U. B., Messner, P. \& Pum, D. (1988). Analysis of crystalline bacterial surface layers by freeze etching, metal-shadowing, negative staining and ultrathin sectioning. Methods Microbiol 20, $29-60$.

Spanevello, M. D., Yamamoto, H. \& Patel, B. K. C. (2002). Thermaerobacter subterraneus sp. nov., a novel aerobic bacterium from the Great Artesian Basin of Australia, and emendation of the genus Thermaerobacter. Int J Syst Evol Microbiol 52, 795-800.

Stackebrandt, E., Rainey, F. A. \& Ward-Rainey, N. L. (1997). Proposal for a new hierarchic classification system, Actinobacteria classis nov. Int J Syst Bacteriol 47, 479-491.

Van de Peer, Y., Jansen, J., De Rijk, P. \& De Wachter, P. (1997). Database on the structure of small ribosomal subunit RNA. Nucleic Acids Res 25, 111-116.

Wardle, D. A., Yeates, G. W., Barker, G. M. \& Bonner, K. I. (2006). The influence of plant litter diversity on decomposer abundance and diversity. Soil Biol Biochem 38, 1052-1062.

Xu, L. H., Li, Q. R. \& Jiang, C. L. (1996). Diversity of soil actinomycetes in Yunnan, China. Appl Environ Microbiol 62, 244-248. 